\title{
Correction \\ Correction: Fovell, R.G.; Gallagher, A. Winds and Gusts during the Thomas Fire. Fire 2018, 1, 47
}

\author{
Robert G. Fovell * (1) and Alex Gallagher
}

Citation: Fovell, R.G.; Gallagher, A.

Correction: Fovell, R.G.; Gallagher, A Winds and Gusts during the Thomas Fire. Fire 2018, 1, 47. Fire 2022, 5, 10.

https://doi.org/10.3390/

fire5010010

Received: 31 December 2021

Accepted: 4 January 2022

Published: 18 January 2022

Publisher's Note: MDPI stays neutral with regard to jurisdictional claims in published maps and institutional affiliations.

Copyright: (c) 2022 by the authors Licensee MDPI, Basel, Switzerland. This article is an open access article distributed under the terms and conditions of the Creative Commons Attribution (CC BY) license (https:// creativecommons.org/licenses/by/ $4.0 /)$.
Department of Atmospheric and Environmental Sciences, University at Albany, SUNY, Albany, NY 12222, USA; agallagher@albany.edu

* Correspondence: rfovell@albany.edu

The authors wish to make the following corrections to this paper [1]:

Error in Section 3.1

The authors found a typo in Section 3.1, it is in the following sentence:

"ASOS and AWOS data from MADIS use complex METAR reporting rules [32] that (in the United States) zero out light $(<0.5 \mathrm{~m} / \mathrm{s})$ winds and seriously compromise the gust record [33]."

$0.5 \mathrm{~m} / \mathrm{s}$ should be $1.5 \mathrm{~m} / \mathrm{s}$.

The corrected sentence appears below.

"ASOS and AWOS data from MADIS use complex METAR reporting rules [32] that (in the United States) zero out light $(<1.5 \mathrm{~m} / \mathrm{s})$ winds and seriously compromise the gust record [33]."

The authors would like to apologize for any inconvenience caused to the readers by these changes.

\section{Reference}

1. Fovell, R.G.; Gallagher, A. Winds and Gusts during the Thomas Fire. Fire 2018, 1, 47. [CrossRef] 